Article

\title{
Ecumenism: Rapprochement Through Co-working to Reconciliation
}

\section{Cyril Hovorun}

Huffington Ecumenical Institute, Loyola Marymount University, 1 LMU Drive, Los Angeles, CA 90045, USA; hei@lmu.edu

Academic Editor: John A. Jillions

Received: 6 February 2017; Accepted: 7 April 2017; Published: 27 April 2017

\begin{abstract}
This paper explores some forms of interaction between the Catholic and Orthodox churches in different contexts. Some of these forms are helpful, but not always efficient, and some are not helpful. Theological dialogues belong to the former category of interactions: they are helpful, but not efficient. Alliances on an ideological basis, for instance on the basis of "traditional values," are unhelpful, because they polarise the churches internally. This article instead proposes a collaboration in the public domain as an alternative way of rapprochement between the two churches. The Ukrainian Maidan (the revolution of 2014) exemplifies a co-working space, which proved to be efficient for restoring trust between Orthodox and Greek Catholics.
\end{abstract}

Keywords: ecumenical dialogues; culture wars; ideology; public domain; maidan

What has been called the Great Schism between eastern and western Christianity was not a one-day event. It was not even a one-year event, although the formal year of their separation is believed to be 1054, when the delegation of the Roman See to Constantinople placed on the altar in Hagia Sophia the bull of excommunication of the patriarch Michael Keroularios, and was excommunicated in return. The process of separation began long before that date and was finalised long after (Louth 2007). It lasted for centuries and was complicated; it comprised currents on different levels and was delayed by many setbacks. Similarly, when the restoration of unity happens, it will not be a one-day or even a one-year event. It will last long decades, maybe even centuries. As a matter of fact, this process is already happening. Less time has passed since reconciliation began than it had taken for the process of separation. As regards complexity, the process of reconciliation mirrors the complexity of the separation at the turn of the second millennium. It features multi-layer currents and multiple setbacks.

In what follows, we will consider these three forms of the rapprochement between the Catholic and Orthodox churches: theological dialogue, "ideological ecumenism," and co-working in the public square. Each of these forms has its advantages and disadvantages. Some of them are healthier and more authentic, and others are less so.

At the top of the process of reconciliation, there is the official international Orthodox-Catholic dialogue (Savvatos 2014, pp. 487-89). It is conducted by a commission, whose official name is "The Joint International Commission for Theological Dialogue Between the Catholic Church and the Orthodox Church." This commission held its first session in 1980, a year after a formal decision to have such a dialogue was taken by Pope John Paul II and Patriarch Demitrios of Constantinople. The initial momentum for this dialogue was the first meeting since the Middle Ages between the Pope of Rome, Paul VI, and the Patriarch of Constantinople, Athenagoras, in January of 1964 in Jerusalem. The follow-up of that meeting was the lifting of the anathemas from 1054. This was a rather symbolic act, which signified a turning point from the pattern of confrontation to the pattern of dialogue in the relations between the two churches. 
The logic of any theological dialogue, including the one between the Orthodox and Catholic churches, can be schematised in the following way. It is commonly believed that all major splits in the church were caused by theological disagreements or, to be precise, by theological formulas. In the case of the Orthodox-Catholic relationship, it was the insertion of Filioque to the Nicean creed. After the church hierarchs disagreed on these formulas, they decided to cease communion with each other. The restoration of unity, therefore, has to follow a reversed path: the hierarchs should agree on common theological formulas and then could resume communion with each other. Theological dialogues, thus, struggle to work out common theological formulas as an instrument of the restoration of unity.

This logic, however, has a couple of faults. First, it is based on the belief in the "magic" power, as it were, of theological formulas. This belief goes back to the era of scholasticism. This era began not in Western Europe in the Middle Ages, but in Asia Minor in the Late Antiquity. Scholasticism emerged in the fourth century and turned into a main theological method in the second part of the fifth century, approximately during the generation of the disciples of Cyril of Alexandria. ${ }^{1}$ Cyril, who was the most important theological figure in that period, concluded the era when the meaning of theological formulas mattered more than their wording. That is why he was not consistent in the use of theological language, as for instance in the case of the Christological formula, "one nature of the incarnated God Word." ${ }^{2}$ This was not yet a formula, but a part of a theological narrative. The disciples of Cyril, however, turned this dictum to a formula, and disagreed on its interpretation.

Some of them synthesised a new Christological formula on the basis of the languages of Cyril and Pope Leo. This formula, "one hypostasis of Jesus Christ in two natures," was adopted by the council of Chalcedon (Hovorun 2015a, p. 451). Another group of Cyril's disciples, under the leadership of the patriarch of Alexandria Dioskoros and the patriarch of Antioch Severos, opposed the Chalcedon and insisted that the words of the Alexandrian archbishop should be taken literally. Both parties departed from Cyril's flexible attitude toward theological language and arrived at a scholastic perception of it.

As mentioned above, this early Byzantine scholasticism featured a belief in the almost magical power of theological formulas. This attitude to theological formulas, as if they were "spells," became one of the reasons for the divisions between the churches in the fifth-sixth centuries. One group refused to accept one nature in Jesus, while for the other, two natures was unacceptable. Their insistence on a particular wording was different from the Arian controversy a century earlier. Unlike the terms "one" and "two natures," the terms homoousios (consubstantial), homoiousios (of a similar substance), and homios (a similar) were not synonyms, but signified completely different relationships between the Father and the Son in the Trinity. This difference in attitude to theological formulas explains why, in contrast to the Nicean theologians in the fourth century, the so-called neo-Chalcedonian theologians, who followed the council of Chalcedon and synthesised its language with the language of Cyril (Hovorun 2015b, pp. 106-24), in the sixth century accepted the language of the anti-Chalcedonians and agreed that the formula "one nature" can be used together with "two natures." Unfortunately, it was already too late to heal the division between Chalcedonians and anti-Chalcedonians, which had already happened and had become institutionalised in parallel ecclesial structures. Thus, it is not a coincidence that the first great schism between the churches in the fifth century; Rome and Constantinople on the one side, and Alexandria and Antioch on the other, happened in the period of the rise of early Byzantine scholasticism. A century before that, when an even more serious theological issue of Arianism erupted, it did not cause the same sort of schism between Arians and Niceans. This was partially because, in the fourth century, theologians could still go around formulas and accepted different interpretations of the words.

I argue about this in my presentation "Cyril of Alexandria: a phenomenological theologian?" (Hovorun 2015a, pp. 378-444).

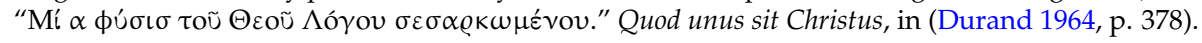


When, in the modern era, theologians put into theological formulas the same faith as in the fifth century, they act anachronistically. In the era of abundance of hermeneutical methods, theological formulas became disenchanted. By invoking them, theologians can no longer change the reality of the church life-something they were able to do in the period of Late Antiquity and the Middle Ages. On the one hand, unity of the church cannot happen without agreeing on theological formulas. On the other hand, even when churches agree on common theological formulas, these formulas do not have the power to restore communion between churches anymore.

A second misleading assumption regarding theological formulas, as they are being discussed in the dialogues, is that they are exclusively about theology. In the era of Late Antiquity, there were not many semantic instruments to express people's cultural and political concerns. Theology instead offered the most elaborated language to talk about non-theological issues. That is why theological formulas were underpinned by various political and social agendas; they were not just about theology. For instance, Arianism, with its stress on the monarchy of the Father in the Trinity, effectively enhanced the monarchy of the Christian emperors. ${ }^{3}$ Later theological movements, such as Severianism, Monothelitism, and Iconoclasm, also contributed to the consolidation of imperial authority.

With the passage of time, theological formulas often turned into identities. Large groups of people, which today would be called nations, adopted them as their distinct characteristics. For instance, the emergence of Coptic ethnicity was facilitated by the rejection of the council of Chalcedon by many Egyptian Christians. Armenians and Georgians also became polarised by their attitude to the Chalcedon. Theological formulas turned into cultural phenomena and thus lost, to a great extent, their original theological meaning. This means, for instance, that pro- and anti-Chalcedonian identities of different Christian groups in the Middle East today do not imply that those groups understand or give any significance to the Chalcedon as a theological phenomenon. Chalcedon now matters as a cultural phenomenon only. Most people are not aware of the theological differences that had led to the separation between the Eastern and Oriental churches in the fifth century. Nevertheless, they would protect these differences as their identity against anyone who would try to undermine them. If theologians and bishops would tell them that there are no theological differences anymore, this can be perceived by the people on the both sides of the Chalcedonian divide as an existential threat to who they are.

All these cultural connotations that theological formulas absorbed during their historic journey make them an insufficient instrument for the restoration of Christian unity in our days. When the official dialogues try to arrive at a common formula, they usually disregard its cultural connotations. As a result, the method of theological formulas alone, unfortunately, cannot secure the restoration of unity. What the theological formulas did in the past cannot be undone in the same way-by casting their spell on the divide.

The dialogue between the Eastern and Oriental churches has demonstrated this persuasively. This is the earliest of the bilateral dialogues (since 1964) and is the only one that has been completed successfully. ${ }^{4}$ The dialogue resulted in two theological statements: one was adopted in 1989 in the Anba Bishoy monastery in Egypt, and the other, a more elaborated version of the previous one, was adopted in 1990 in Chambésy, Switzerland. ${ }^{5}$ The Chambésy statement contains theological formulas based on the Christological language of Cyril of Alexandria. It repeats the wording elaborated in the framework of Neo-Chalcedonianism. The articles of the Chambésy statement were drafted jointly by the Chalcedonian and non-Chalcedonian theologians, and were eventually received by most members

3 This discussion was initiated by Erik Peterson in Der Monotheismus als politisches Problem; ein Beitrag zur Geschichte der politischen Theologie im Imperium Romanum (Peterson 1935).

4 This is a common Eastern and Oriental understanding of the results of this dialogue. What followed the completion of the theological phase of the dialogue, was called a "pastoral" phase, which began in 1993 and was to solve practical issues, such as commemoration of common Saints. See (Ovidiu 2014, pp. 508-28).

5 All the statements of the dialogue are available at (Orthodox Unity n.d.). 
of the dialogue. This was celebrated as a big success, which, however, was not acknowledged by all churches officially. The reasons for this had to do not with theology, but with the role of theological formulas as cultural denominators and people's identities, as described above. It turned out that theological matters do not matter for most Christians in the East any more, at least not to the extent they used to matter when their churches departed from each other. Theology has turned into people's identity, and this identity cannot be changed just by theological formulas. As a result, both Eastern and Oriental churches hesitate to implement the theological results of the dialogue and do not proceed to the restoration of communion.

The same will probably happen to the Orthodox-Catholic dialogue, if one day it will produce a common theological formula, which would resolve the differences between the two traditions. Most likely, such a formula will not lead to the restoration of unity, at least not automatically. This means that, in addition to theology, other issues should be tackled in the framework of the dialogue, including people's identities and culture. In other words, the dialogue should also deal with these questions: what does it mean to be a Catholic or an Orthodox, and how are these identities perceived by the followers of both traditions? These questions make the dialogue more complicated. However, without addressing them, the dialogue will most probable stumble on the same obstacles that the Eastern-Oriental dialogue has stumbled upon.

Dialogue is not a traditional way of solving theological issues. In the Byzantine past, such issues were solved at councils, by the exchange of letters and delegations, and through the mediation of emperors. Dialogue, as a form of conflict-resolution, is a product of modern times and was invented to tackle political problems. This does not, however, make dialogue something alien to the church. Moreover, it has effectively substituted other, more traditional, forms of rapprochement. Now it constitutes the commonest instrument of rapprochement between the churches.

There are also other forms of interaction between the divided churches which can be borrowed from political life. These forms can be both productive and counter-productive.

One of them employs ideological platforms and follows the pattern of the culture wars. The largest clashing political platforms of our time are two ideologies, which can be called "liberal" and "conservative." Their names and polarity reflect mostly the American political system, and as such they should not be applied too generally. Nevertheless, schematic distinction between "liberalism" and "conservatism" can be useful in explaining different ideological currents in the churches, as well as their attitudes to other Christians and to ecumenism.

The divide between "liberal" and "conservative" approaches seems to be stronger than many other divides, including theological ones. Many churches experience internal divisions along this ideological line. Conservative wings in these churches feel closer to each other than to the liberal wings in their own churches. The same applies to the liberal wings. This creates a precondition for what can be called "ideological ecumenism" - a rapprochement between the churches not on a theological basis, but on an ideological one. In this ecumenism, theology is substituted by ideology.

In some sense, this substitution can be effective, because theology does not touch many people in the churches anymore. Only a limited number of enthusiasts can follow theological arguments and make them relevant to their lives and communities. Ideologies, in contrast, are capable of enchanting many more people in the churches, especially when they are rendered in theological languages. As a result, they have more power than theology to mobilise different groups in the churches.

Ideologies, however, do more harm than benefit to the churches. First, unlike theology, which bridges this world with the divine, ideologies keep people confined to the agendas of this world. They emerged in the period of the Enlightenment as a product of secularisation of Christian societies. ${ }^{6}$ As a result, they cannot elevate the human mind and spirit to God. Second, "ideological ecumenism" disintegrates communities from within: it alienates "liberal" and "conservative" members of the

6 I analyse in detail the origins of ideologies in the modern era in "Ideology and Religion" (Hovorun 2016). 
churches and communities from each other. Third, ideologies cannot secure sustainable alliances between followers of the same ideology from different churches.

The history of the American "fundamentalism" during the twentieth century clearly illustrates these shortcomings of the "ideological ecumenism." Soon after "fundamentalist" groups emerged in the 1920s in different Protestant churches in the United States, they began approaching each other. Simultaneously they distanced themselves from more "liberal" groups and thus caused schisms within their own churches. For example, the Northern Presbyterians and Northern Baptists became divided almost equally (Marsden 1980, pp. 164-65). The "fundamentalists" could not reconcile themselves with those whom they called "liberals," because they considered the latter to believe in almost a different religion. Characteristic in this regard is a statement by J. Gresham Machen (1881-1937) from the Princeton Theological Seminary:

In the sphere of religion, in particular, the present time is a time of conflict; the great redemptive religion which has always been known as Christianity is battling against a totally diverse type of religious belief, which is only the more destructive of the Christian faith because it makes use of traditional Christian terminology. This modern non-redemptive religion is called "modernism" or "liberalism." (Machen 1923, p. 2)

At the same time, the "fundamentalists" perceived other "fundamentalists" as belonging to their own religion, even though they belonged to other churches. Thus, "fundamentalist" alliances began developing (Harris 1998, p. 28). One of the earliest of these was the World Christian Fundamentals Association (WCFA). In such alliances, ideological conservatism became more important than the doctrinal differences between denominations. Most of these attempts, however, failed to sustain themselves for a long time or to foster productive cooperation between the churches.

Ideological alliances occurred not only on the basis of conservative ideology. Liberal ideology also sometimes tried to substitute for theology in the ecumenical movements. The largest ecumenical organisation in the world, the World Council of Churches (WCC), which was constructed on theological principles, from time to time fell into the trap of ideological bias, mostly of a leftward tilt. This was, for instance, when the Orthodox churches from the Soviet Block tried to promote through the WCC the ideological agendas of the Communist regimes behind them. These agendas resonated with many "liberal" Christians in the global ecumenical movement.

Moreover, antagonism between pro-ecumenical and anti-ecumenical movements within different churches can be also interpreted as an extrapolation of ideology-based cultural wars. For many anti-ecumenical groups, which exist in most churches, their dissatisfaction with the ecumenical movement is a way to promote their conservative agenda. For instance, radical anti-ecumenists in the Orthodox world, such as groups of the so-called "True Orthodox Christians" or "Old-calendarists," are radical conservatives with clear ideological and political agendas. In a similar way, many groups in the churches who promote the ecumenical agenda are also liberal. Ecumenism for many is a way of expressing and practicing their open liberal views. This does not, however, necessarily undermine their desire for Christian unity.

A recent example of "ideological ecumenism" is an attempt to establish an alliance between the Russian Orthodox and Roman Catholic churches. This initiative was suggested by the Russian church. The logic of such an offer from Moscow is explained by the following. Soon after Patriarch Kirill was elected as the new primate of the Russian Orthodox Church in 2010, he led the church in a strictly conservative direction. "Liberals" were libelled as not-quite-Orthodox, and conservatism was proclaimed a standard of Orthodoxy. At that time, the pope of Rome was a conservative, Benedict XVI. The coincidence of two primates who promoted a similar conservative agenda urged some to promote an alliance between the two churches on the basis of this agenda. Fortunately, this initiative was not picked up by Rome. It is unlikely that such an alliance would have survived under the more liberal Pope Francis.

The political framework offers to the churches not only temptations, but also healthy opportunities for rapprochement. This is particularly the case when the churches work together for the same causes 
of justice and solidarity. These causes are not ideological. Unlike ideologies, which project political programs onto religion and thus reduce the theological scope of the church, causes of justice and solidarity project the principles of Christian faith onto the public domain. These causes do not reduce or constrain the nature and purpose of the church, but implement its theological vision through social action. Therefore, this sort of social activity of the church does not incur the same sort of reductions that ideologies do. It does not divide churches according to ideological criteria, but actually bridges different ideological platforms. When churches struggle together for the same causes of justice and solidarity, they grow closer to each other. This can be illustrated by the following scheme (Figure 1):

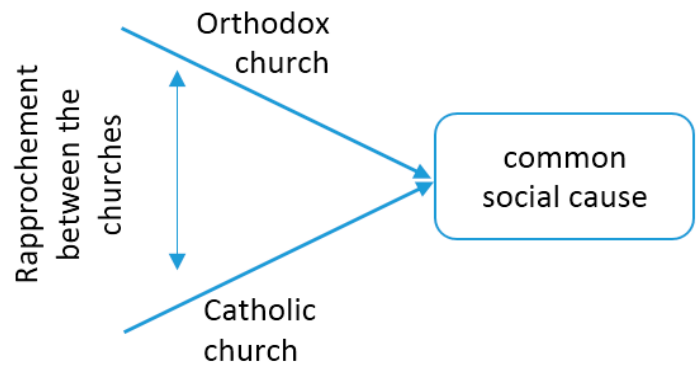

Figure 1. Rapprochement between the churches in the public square.

There are good examples that illustrate how ecumenically effective the struggle of different churches for the same social causes can be. One was the campaign against apartheid, which consolidated the South African churches, particularly in the framework of the South African Council of Churches (SACC). This ecumenical organisation became an inter-denominational and non-ideological platform for overthrowing apartheid, especially under the leadership of the Anglican Archbishop of Cape Town, Desmond Tutu. After the apartheid was officially abandoned and condemned, the churches continued working together in restoring justice and integrity to the society in South Africa, through the Truth and Reconciliation Commission. Similar commissions in other countries, which had been torn by political abuses and totalitarianisms, have also been supported by different churches. Through participation in these commissions, the churches contributed to the restoration of justice and solidarity in their societies. This participation also helped them become closer to each other and contributed to genuine ecumenism.

Another example is more recent: the so-called "Revolution of dignity" in Ukraine. This happened during the winter 2013-14, when hundreds of thousand Ukrainians came to the central square of the country's capital Kyiv, the Maidan, to protest against the injustice and authoritarianism imposed by former President Viktor Yanukovych. His regime tried to forcefully dissipate the originally and purposely peaceful protests, which caused clashes that led to around one hundred casualties. Protesters fell from the fire of snipers and police, which led to the ousting of President Yanukovych, who fled to Russia.

During all three months of the protests, the Ukrainian churches were together with the people at the Maidan, each church to a different extent. The protesters prayed together, regardless of their ecclesial affiliations, and were encouraged by clergy of different churches. The Ukrainian churches, before the manifestations at the Maidan, felt quite hostile to each other. The confrontation was particularly severe between the Orthodox churches of the Moscow and Kyiv Patriarchate, as well as between the Moscow Patriarchate and the Ukrainian Greek Catholic Church. When the Maidan happened, however, even the priests (though not the bishops) of the Moscow Patriarchate came there together. They prayed on the central stage of the protests, despite their differences and hostilities in the past. The Maidan, thus, became an important ecumenical event and spurred on momentum for rapprochement between the churches, especially on the level of lay people and clergy (Hovorun 2014). It brought together the churches, which were previously not able even to begin a dialogue with each other. In this way the Maidancreated a space that enabled the churches to achieve more than any dialogue managed to do. 
Unfortunately, after the victory of the "Revolution of dignity," some churches withdrew from the common public space and locked themselves up in their usual rhetoric of exclusion and condemnation of others. In particular, this happened to the Ukrainian Orthodox Church of the Moscow Patriarchate. The momentum towards rapprochement, which was created by the Maidan, was quenched. This occurred mostly because of the Russian aggression against Ukraine that followed. Russian propaganda flooded Ukraine with "post-truth" filled with the messages of hatred and division. The Moscow Patriarchate in Ukraine appeared most vulnerable to the effects of this propaganda.

Nevertheless, the Maidan showed the Ukrainian churches a pattern towards reconciliation, which can parallel more traditional dialogues. Particularly interesting is how the Orthodox and Greek Catholic churches came along. At the public square of the Maidan, their faithful and priests stood next to each other. The Maidan, thus, showed that the Orthodox and Greek Catholic church can be best friends and not necessarily antagonists. This can serve as an example for the Orthodox and Catholic churches. Pursuing common good in the public domain can help them continue moving closer to each other. This does not mean that the co-working of the churches in the public square should be a substitute dialogue and other ways of rapprochement. It only means that such work can and should be done in parallel to theological conversations.

Acknowledgments: This article is published as a part of fellowship at the Huffington Ecumenical Institute at Loyola Marymount University in Los Angeles.

Conflicts of Interest: The author declares no conflict of interest.

\section{References}

de Durand, G. M. 1964. Cyrille d'Alexandrie. Deux dialogues christologiques. L'antiquité classique 33: 508-11. Harris, Harriet A. 1998. Fundamentalism and Evangelicals. Oxford and New York: Oxford University Press.

Hovorun, Cyril. 2014. Christians in Ukraine: Ecumenism in the Trenches. Available online: http://www.catholicworldreport.com/Item/2970/christians_in_ukraine_ecumenism_in_the_trenches. aspx\#.Uzt2Rq1dVWg (accessed on 13 April 2017).

Hovorun, Cyril. 2015a. Cyril of Alexandria: A phenomenological theologian? Paper presented at the XVII International Conference on Patristic Studies, Oxford, UK, August 10-14.

Hovorun, Cyril. 2015b. Maximus, a Cautious Neo-Chalcedonian. In The Oxford Handbook of Maximus the Confessor. Edited by Pauline Allen and Bronwen Neil. Oxford: Oxford University Press.

Hovorun, Cyril. 2016. Ideology and Religion. Kyiv-Mohyla Humanities Journal 3: 23-35. [CrossRef]

Louth, Andrew. 2007. Greek East and Latin West: the Church, AD 681-1071. Crestwood: St. Vladimir's Seminary Press.

Machen, J. Gresham. 1923. Christianity and Liberalism. New York: Macmillan.

Marsden, George M. 1980. Fundamentalism and American Culture: The Shaping of Twentieth Century Evangelicalism, 1870-1925. New York: Oxford University Press.

Orthodox Unity. Various Documents Concerning Eastern Orthodox and Oriental Orthodox Joint Commission and Unity: Official Statements. Available online: https:/ / orthodoxjointcommission.wordpress.com/category/ official-statements (accessed on 4 February 2017).

Ovidiu, Ioan. 2014. Eastern Orthodox-Oriental Orthodox Dialogue-A Historical and Theological Survey. In Orthodox Handbook on Ecumenism: Resources for Theological Education. Edited by Panteles Kalaitzides, Thomas E. FitzGerald, Cyril Hovorun, Aikaterini Pekridou, Nikolaos Asproulis, Dietrich Werner and Guy Liagre. Oxford: Regnum, pp. 508-28.

Peterson, Erik. 1935. Der Monotheismus als politisches Problem; ein Beitrag zur Geschichte der politischen Theologie im Imperium Romanum. Leipzig: Hegner.

Savvatos, Chrysostomos. 2014. Orthodox Dialogue with the Roman Catholic Church. In Orthodox Handbook on Ecumenism: Resources for Theological Education. Edited by Panteles Kalaitzides, Thomas E. FitzGerald, Cyril Hovorun, Aikaterini Pekridou, Nikolaos Asproulis, Dietrich Werner and Guy Liagre. Oxford: Regnum. 